\title{
Circulating Bovine Lymphocytes Contain Receptors for Parathyroid Hormone
}

\author{
Itsuo Yamamoto, John T. Potts, Jr., and Gino V. Segre, Endocrine Unit, \\ Department of Medicine, Massachusetts General Hospital, Harvard \\ Medical School, Boston, Massachusetts 02114
}

\begin{abstract}
A B S T R A C T No cell type practicably obtainable in vivo, such as blood cells, is known to contain parathyroid hormone (PTH) receptors; this deficiency has hampered investigation of receptor regulation. Second, PTH in vivo is among the potent stimulators of osteoclastic activity, although no direct hormonal effects on these cells have been identified. Several lines of evidence suggest that cells of the immune system may mediate PTH effects on osteoclasts. We, therefore, studied bovine blood cells for the presence of PTH receptors and PTH-stimulated adenylate cyclase. Using an analogue of bovine $\mathrm{PTH},{ }^{125} \mathrm{I}$-labeled $\left[\mathrm{Nle}^{8}, \mathrm{Nle}^{18}, \mathrm{Tyr}^{34}\right] \mathrm{bPTH}-(1--34)$ amide, we found PTHspecific binding to intact, nonadherent mononuclear cells (lymphocytes) and PTH-stimulated adenylate cyclase in plasma membranes prepared from these cells, and not with cells or membranes from other blood cells. Lymphocytes may serve to study the effects of physiologic and pathologic perturbations on PTH-receptor function in vivo. Exploration of PTH-related lymphocyte responses may help define the relation between cells of the immune system and osteoclastic bone resorption.
\end{abstract}

\section{INTRODUCTION}

Receptors for several peptide hormones, including insulin, growth hormone, somatomedin, glucagon, and somatostatin, have been identified on circulating mononuclear cells (1-4). Although there may be correlations between the presence of specific hormone receptors on mononuclear cells and physiologically

\footnotetext{
Address reprint requests to Dr. Segre.

Received for publication 27 August 1982 and in revised form 9 November 1982.
}

relevant responses of these cells to hormonal stimulation, to date, the major importance of these cells to understanding hormone/receptor interactions is that hormone receptors on leukocytes appear to have response characteristics identical to those of cells from defined target organs. Thus, for example, assessment of mononuclear cell receptors has yielded insights into regulation of receptors during development (5) and into normal and pathologic alterations in hormone receptors, particularly the obesity-dependent changes in insulin receptors (6). Our search for parathyroid hormone $(\mathrm{PTH})^{1}$ receptors in circulating cells was based, partly, on the expectation that, if a readily accessible cell containing PTH receptors could be identified, we could then address issues relating to receptor regulation in vivo.

\section{METHODS}

Cell preparation. Calf blood with acid citrate dextrose solution was centrifuged at $1,000 \mathrm{~g}$ for $20 \mathrm{~min}$, the buffy coat was removed, and centrifuged repeatedly at $250 \mathrm{~g}$ for $10 \mathrm{~min}$ to remove contaminating platelets. The pellet, suspended in phosphate-buffered saline, $\mathrm{pH} 7.5$, supplemented with $10 \%$ fetal calf serum, was layered on Ficoll-Hypaque (density 1.077, Sigma Chemical Co., St. Louis, MO) and centrifuged at $400 \mathrm{~g}$ for $40 \mathrm{~min}$ at $15^{\circ} \mathrm{C}$. After lysis of erythrocytes (RBC) by $30 \mathrm{~s}$ exposure to water, $95 \%$ of the cells recovered from the interface were mononuclear. After hypotonic lysis of the RBC in the pellet, polymorphonuclear cells (PMN) contaminated with mononuclear cells (5-40\%) were recovered. Lymphocyte-enriched mononuclear cells were collected after: $A$, incubation of mononuclear cells for $2 \mathrm{~h}$ at $37^{\circ} \mathrm{C}$ in plastic culture vessels (7); B, exposure of mononuclear cells to carboxyl iron (3-4 $\mu \mathrm{m}, \mathrm{S}-\mathrm{F}, \mathrm{GAF}$ Corp.,

\footnotetext{
${ }^{1}$ Abbreviations used in this paper: PMN, polymorphonuclear cells; PTH, parathyroid hormone; RBC, erythrocytes.
} 
New York, NY) and magnetic removal of cells that ingested the iron (8); C, elution of mononuclear cells from columns containing glass beads $(1 \mathrm{~mm}$, Thomas Co., Philadelphia, PA) (9). Monocyte-enriched mononuclear cells were harvested by collecting cells adherent to plastic culture vessels after incubation for $2 \mathrm{~h}$ at $37^{\circ} \mathrm{C}(7)$. Lymphocyte-enriched cell populations prepared by methods $\mathrm{A}, \mathrm{B}$, and $\mathrm{C}$ were contaminated with 20,2 , and $5 \%$ monocytes, respectively; the monocyte-enriched population was contaminated with $9 \%$ lymphocytes. Cells were identified by microscopical examination, latex bead $(0.85 \mu \mathrm{m}$, Difco, Detroit, MI) ingestion (10) and nonspecific esterase staining (11). Viability of all cells was $>90 \%$ as assessed by exclusion of trypan blue.

Radioligand binding and adenylate cyclase assay. Binding of PTH was studied using a fully active radioiodinated analogue of bovine PTH, ${ }^{125} \mathrm{I}$-labeled $\left[\mathrm{Nle}^{8}, \mathrm{Nle}^{18}, \mathrm{Tyr}^{34}\right] \mathrm{bPTH}-$ (1--34)amide (12), prepared as reported previously (13). Leukocytes $\left(10^{8} / \mathrm{ml}\right)$ or $\mathrm{RBC}\left(5 \times 10^{9} / \mathrm{ml}\right)$ were incubated with $100,000 \mathrm{cpm}(20 \mathrm{fmol})$ of the radioligand in $250 \mu \mathrm{l}$ of $50 \mathrm{mM}$ Tris-HCl, $100 \mathrm{mM} \mathrm{NaCl}, 5 \mathrm{mM} \mathrm{KCl}, 0.1 \mathrm{mM}$ EDTA and $5 \%$ horse serum, $\mathrm{pH} 7.5$, for $2 \mathrm{~h}$ at $15^{\circ} \mathrm{C}$. To separate cell-bound radioligand from free tracer, $200 \mu \mathrm{l}$ of the incubation medium was layered onto $200 \mu \mathrm{l}$ of binding buffer containing Metrizamide (density 1.060, Nyegaard \& Co., Oslo, Norway) in a 400- $\mu$ l microcentrifuge tube. After centrifugation at $400 \mathrm{~g}$ for $5 \mathrm{~min}$ at $4^{\circ} \mathrm{C}$, the supernatant was aspirated, and the tip of the microtube was cut and counted for ${ }^{125} \mathrm{I}$. Nonspecific binding is defined as residue binding in the presence of $10^{-6} \mathrm{M}$ of $\left[\mathrm{Nle}^{8}, \mathrm{Nle}^{18}, \mathrm{Tyr}^{34}\right] \mathrm{bPTH}-(1-$ 34)amide. Specific binding is derived by subtracting nonspecific binding from total binding.

Adenylate cyclase activity was measured by methods previously reported (13). For collection of cell membranes, cells were homogenized in a tightly fitting Dounce homogenizer;

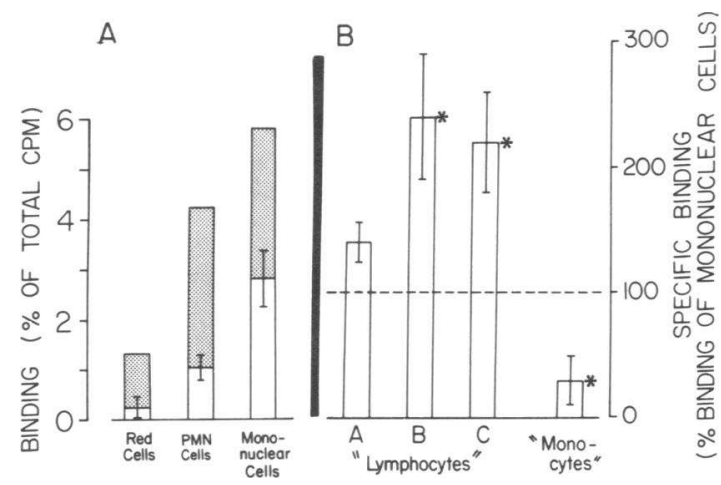

FigURE 1 A Binding of ${ }^{125}$ I-labeled $\left[\mathrm{Nle}^{8}, \mathrm{Nle}^{18}, \mathrm{Tyr}^{34}\right] \mathrm{bPTH}$ (1--34)amide to RBC, PMN, and mononuclear-cells. Unshaded and shaded areas represent specific and nonspecific binding, respectively. The data shown are the mean of six separate experiments, each done in triplicate (mean \pm SEM). $B$ Comparison of the specific binding of ${ }^{125}$ I-labeled $\left[\mathrm{Nle}^{8}, \mathrm{Nle}^{18}, \mathrm{Tyr}^{{ }^{4}}\right] \mathrm{bPTH}-(1--34)$ amide to subpopulations of mononuclear cells. Lymphocyte-enriched populations were obtained by three methods (A, B, and C; see text). PTHspecific binding in each subpopulation of mononuclear cells is compared with the binding observed using the same number of undifferentiated mononuclear cells (mean \pm SEM of five separate experiments, each done in triplicate) ${ }^{\circ} P<0.05$ vs. binding of the radioligand to undifferentiated mononuclear cells. the crude membranes were collected by centrifugation at $13,000 \mathrm{~g}$ for $15 \mathrm{~min}$ at $4^{\circ} \mathrm{C}$ and suspended in $50 \mathrm{mM}$ Tris$\mathrm{HCl}, \mathrm{pH} 7.5$.

\section{RESULTS}

The PTH radioligand bound specifically to the mononuclear-cell fraction. No significant specific binding was seen to RBC or PMN (Fig. 1A). Specific binding in the PMN fraction varied directly with the degree of contamination with mononuclear cells. Repetitive centrifugation on gradients of Ficoll-Hypaque resulted in decreased binding to cells in the PMN cell fraction that correlated closely with the reduced number of contaminating mononuclear cells. Thus, the apparent PTH-specific binding to this cell fraction appears to be related to binding to contaminating mononuclear cells. Regardless of the methods used to obtain enriched subpopulations of mononuclear cells, specific binding of ${ }^{125} \mathrm{I}-$ labeled $\left[\mathrm{Nle}^{8}, \mathrm{Nle}^{18}, \mathrm{Tyr}^{34}\right] \mathrm{bPTH}-(1--$ 34)amide per cell was greater in cells having the properties of lymphocytes than in the parent mononuclearcell fraction from which the lymphocyte-enriched population had been obtained (Fig. 1B). Specific binding to monocytes was only a small fraction of the binding to the parent mononuclear-cell fraction, and it was consistent with the degree of contamination of the monocyte population with the other mononuclear cells (Fig. 1B). Binding of the radioligand to the lymphocyte-enriched cell population is specific for biologically active PTH peptides. The apparent dissociation constant $\left(K_{d}\right)$ of intact bovine PTH and [Nle ${ }^{8}$, $\mathrm{Nle}^{18}, \mathrm{Tyr}^{34}$ ]bPTH-(1--34)amide are $2 \times 10^{-9} \mathrm{M}$ and 1

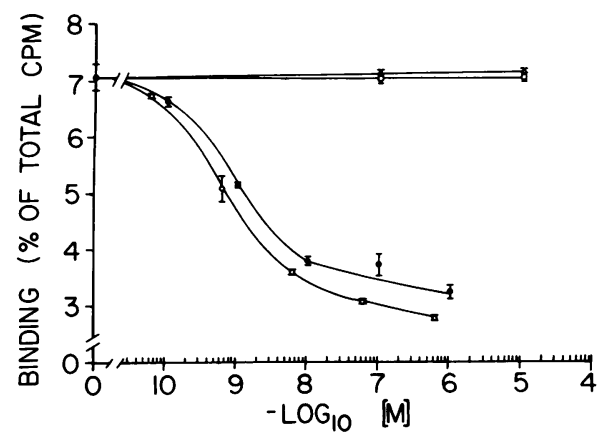

FIgURE 2 Specificity of PTH binding. Lymphocyte-enriched cells (eluted from columns of glass beads) were incubated with radioligand $(100,000 \mathrm{cpm})$ and various concentrations of intact bovine PTH (๑), $\left[\mathrm{Nle}^{8}, \mathrm{Nle}^{18}, \mathrm{Tyr}^{34}\right] \mathrm{bPTH}-$ (1--34)amide $(O)$ inactive PTH fragments (bovine PTH-1(1-13), bovine PTH-(53--84), and human PTH-(28--54) $(\Delta)$, and hormone unrelated to PTH (bovine insulin, somatostatin, human leutinizing hormone, and ACTH) (ם). Only intact bovine PTH and $\left[\mathrm{Nle}^{8}, \mathrm{Nle}^{18}, \mathrm{Tyr}^{34}\right]$ bPTH-(1--34)amide competed with the radioligand (mean $\pm S E M$ of quadruplicate samples). 
$\times 10^{-9} \mathrm{M}$, respectively. No competition was seen by $10^{-5} \mathrm{M}$ of biologically inactive PTH peptides or unrelated hormones (Fig. 2). At $15^{\circ} \mathrm{C}$, binding reaches equilibrium within $2 \mathrm{~h}$. After reaching equilibrium at $15^{\circ} \mathrm{C}$ and after removal of unbound radioligand by extensive washing, $15 \%$ of the radioligand is dissociated after $1 \mathrm{~h}$. Binding is temperature dependent, occurring more rapidly at $37^{\circ} \mathrm{C}$ and more slowly at $4^{\circ} \mathrm{C}$. In studies to be reported elsewhere, we have shown that PTH-specific binding to the lymphocyteenriched cell population is saturable, and the functional properties of fragments and analogues of bovine PTH are very similar to those observed with PTH receptors in canine renal plasma membrane (13).

Intact PTH stimulated adenylate cyclase in plasma membranes prepared from mononuclear cells, but not in plasma membranes from other blood cells. Furthermore, PTH stimulated adenylate cyclase only in membranes prepared from adherent cells (Fig. 3, inset). Maximal activation was seen with intact PTH at

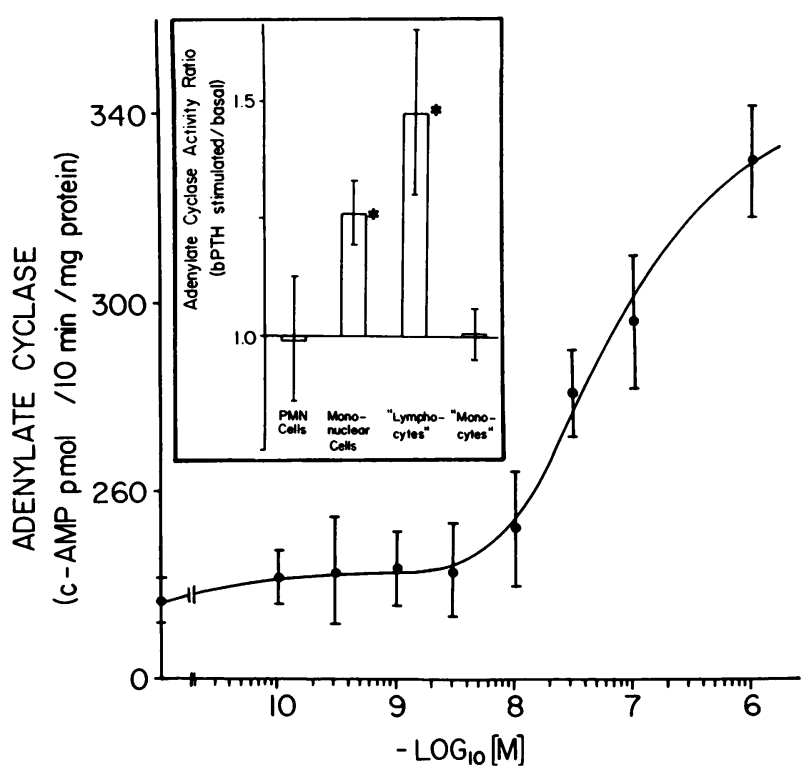

FigURE 3 PTH-stimulated adenylate cyclase in plasma membranes $(30 \mu \mathrm{g})$ from lymphocyte-enriched cells (eluted from columns of glass beads) is dose dependent with a halfmaximal and maximal responses to intact bovine PTH of 4 $\times 10^{-8} \mathrm{M}$ and $10^{-6} \mathrm{M}$, respectively. Data are the mean $\pm S E M$ of quadruplicate samples. Four separate experiments showed similar results. Inset: PTH-stimulated adenylate cyclase in crude membranes from PMN, mononuclear-cells, lymphocyte-enriched cells (eluted from columns of glass beads), and monocyte-enriched cells. Plasma membranes $(30 \mu \mathrm{g})$ were incubated for $10 \mathrm{~min}$ at $37^{\circ} \mathrm{C}$ in the presence or absence of intact bovine PTH $\left(10^{-6} \mathrm{M}\right)$. Data are expressed as the ratio of PTH-stimulated enzyme activity over basal activity (mean \pm SEM of five separate experiments, each done in triplicate). ${ }^{\bullet} P<0.05$ vs. basal activity. a concentration of $10^{-6} \mathrm{M}$, and the half maximal response occurred at $4 \times 10^{-8}$ (Fig. 3 ).

\section{DISCUSSION}

Our studies demonstrate the presence of PTH receptors and PTH-stimulated adenylate cyclase in circulating bovine mononuclear blood cells. Moreover, PTH receptors are associated with lymphocyte-enriched cells, and most likely with $\mathrm{T}$ lymphocytes, which are the predominant cells that do not adhere to glass beads (9). Stimulation of adenylate cyclase by PTH and calcitonin in homogenates of murine peritoneal macrophages has been reported previously (14). However, we did not observe PTH binding to bovine circulating macrophages, the monocytes, nor did plasma membranes from these cells contain PTH-responsive adenylate cyclase.

Our observations are of interest for two major reasons; first, identification of $\mathrm{PTH}$ receptors on a readilyaccessible cell should permit detailed studies of changes in PTH receptors accompanying disease states, such as hypoparathyroidism and various forms of primary and secondary hyperparathyroidism, and also may lead to uncovering inherited or acquired defects in PTH-receptor function. We have found in preliminary studies that human lymphocytes contain PTH receptors, a finding that suggests that inquiry into receptor regulation also will be possible in clinical states. Second, although PTH is known to have potent effects on osteoclastic activity and differentiation in vivo, direct effects of PTH on osteoclasts in vitro have not been convincingly demonstrated. Moreover, several lines of evidence suggest that lymphocytes, particularly $T$ lymphocytes, may play a critical role in bone remodeling, a process requiring osteoclastic activity. Markedly delayed bone turnover has been reported in athymic nude mice, animals that lack mature $\mathrm{T}$ lymphocytes (15). Second, decreased thymic mass and abnormal lymphocyte responses to mitogens have been reported in osteopetrotic rats $(16,17)$, and bone resorption can be restored in osteopetrotic mice receiving infusions of normal splenic lymphocytes (18). Alternatively, lymphokine(s) secreted by lymphocytes have been shown to augment osteoclastic function (19). Our data, showing direct actions of PTH on lymphocytes, are worthy of further exploration in regard to possible lym phocyte-mediated bone resorptive actions.

\section{ACKNOWLEDGMENTS}

We thank Dr. Michael Rosenblatt and Dr. Henry Keutmann for providing $\left[\mathrm{Nle}^{8}, \mathrm{Nle}^{18}, \mathrm{Tyr}^{34}\right] \mathrm{bPTH}-(1--34)$ amide, bovine PTH, and other peptides. Dr. Segre is a recipient of Research Career Development Award AM 00070 from National Institutes of Health.

This work was supported by grant AM 11794 from the National Institutes of Health. 


\section{REFERENCES}

1. Gavin, J. R., III, P. Gordon, J. A. Roth, J. A. Archer, and D. N. Buell. 1973. Characteristics of human lymphocyte insulin receptors. J. Biol. Chem. 248: 2202-2207.

2. Thorsson, A. V., and R. L. Hintz. 1977. Specific ${ }^{125} \mathrm{I}-$ somatomedin receptor on circulating human mononuclear cells. Biochem. Biophys. Res. Commun. 74: 15661573.

3. Goldstein, S., M. Blecher, R. Binder, P. V. Perrino, and L. Recant. 1975. Binding of glucagon and insulin to human circulating mononuclear cells in diabetes mellitus. Endocr. Res. Commun. 2: 367-376.

4. Bhathena, S. J., J. Louil, G. P. Schechier, R. S. Redman, L. Wahl, and L. Recant. 1981. Identification of human mononuclear leukocytes bearing receptors for somatostatin and glucagon. Diabetes. 30: 127-131.

5. Rosenfeld, R., A. V. Thorsson, and R. L. Hintz. 1979. Increased somatomedin receptor sites in newborn circulating mononuclear cells. J. Clin. Endocrinol. Metab. 48: 456-461.

6. Archer, J. A., P. Gorden, J. R. Gavin, III, M. A. Lesniak, and J. Roth. 1973. Insulin receptors in human circulating lymphocytes, application to the study of insulin resistance in man. J. Clin. Endocrinol. Metab. 36: 627-635.

7. Dayer, J. M., S. H. Passwell, E. E. Schneeberger, and S. M. Krane. 1980. Interactions among rheumatoid synovial cells and monocyte-macrophages: production of collagenase-stimulating factor by human monocytes exposed to concanavalin A or immunoglobulin Fc fragments. J. Immunol. 124: 1712-1720.

8. Geier, S. S., and P. Cresswell. 1980. Monocytes as accessory cells in the human mixed lymphocyte response; lack of requirement at high cell densities. Cell. Immunol. 49: 190-195.

9. Shortman, L., N. Williams, H. Jackson, P. Ruell, and E. Diener. 1974. The separation of lymphocytes from phagocytes on glass bead columns, and its effect on subpopulations of lymphocytes and antibody forming cells. J. Cell Biol. 48: 566-579.
10. Dominguez, J. H., and G. R. Mundy. 1980. Monocytes mediate osteoclastic bone resorption by prostaglandin production. Calcif. Tissue Int. 31: 29-34.

11. Yam, L. T., C. Y. Li, and W. H. Crosby. 1971. Cytochemical identification of monocytes and granulocytes. Am. J. Clin. Pathol. 55: 283-290.

12. Rosenblatt, M., D. Goltzman, H. T. Keutmann, G. W. Tregear, and J. T. Potts, Jr. 1976. Chemical and biological properties of synthetic, sulfur-free analogues of parathyroid hormone. J. Biol. Chem. 251: 159-164.

13. Segre, G. V., M. Rosenblatt, B. L. Reiner, J. E. Mahaffey, and J. T. Potts, Jr. 1979. Characterization of parathyroid hormone receptors in canine renal cortical plasma membranes using a radioiodinated sulfur-free hormone analogue. J. Biol. Chem. 254: 6980-6986.

14. Minkin, C., L. Blackman, J. Newbrey, S. Pokress, R. Posek, and M. Walling. 1977. Effects of parathyroid hormone and calcitonin on adenylate cyclase in murine mononuclear phagocytes. Biochem. Biophys. Res. Commun. 76: 875-881.

15. Vignery, A., A. Silverglate, M. Horowitz, L. Shultz, and R. Baron. 1981. Abnormal bone remodeling activity in the immunodeficient nude and moth-eaten (Me/Me) mutant mice. Calcif. Tissue Int. 33: 301.

16. Milhaud, G., and M. L. Labat. 1978. Thymus and osteoporosis. Clin. Orthopaed. Rel. Res. 135: 260-271.

17. Milhaud, C., L. Blackman, J. Newbrey, S. Pokress, R. Posek, and M. Walling. 1977. Effects of parathyroid hormone and calcitonin on adenylate cyclase in murine mononuclear phagocytes. Biochem. Biophys. Res. Commun. 76: 875-881.

18. Walker, D. G. 1978. Concentration of splenic lymphocytes with bone-resorption-restorative activity (BBRA) by velocity sedimentation at unit gravity. In Endocrinology of Calcium Metabolism. D. H. Copp and R. V. Talmage, editors. Excerpta Medica, Amsterdam. 105110.

19. Yoneda, T., and G. R. Mundy. 1979. Monocytes regulate osteoclast-activating factor production by prostaglandins. J. Exp. Med. 150: 338-350. 